\title{
JOKES IN SOVIET ESTONIA ${ }^{1}$
}

\author{
Arvo Krikmann
}

\begin{abstract}
This study seeks to offer a brief empirical overview of jokes told in Estonia between the 1960s and the 1990s and introduces and tests two main suppositions: First, the period of Brezhnev's rule (and particularly the last part of it) was a golden era of joke-making in the former USSR and possibly in the countries of the Eastern Bloc in general, and second, a great amount of the joke material (especially political jokes) that circulated in Estonia in the Soviet period was of Russian origin. The article also addresses the issues of the temporal dynamics of the popularity of some joke characters (Juku, Chapaev, Jew Rabinovich, Chukchi, Lenin, Stalin, Nikita (Khrushchev), Brezhnev, Gorbachev); the macaronic telling of Russian loan jokes; jokes of supposedly genuine Estonian origin, including examples of punning in Estonian, and bilingual puns in Estonian and Russian, jokes based on grammar, jokes based on toponyms and anthroponyms, jokes based on popular songs, etc. Brief concluding remarks discuss the general typological structure of canned (folkloric) jokes, the basic nature and specificity of Soviet-era jokes about Socialism, the problem of their function, and the main generic content clusters of jokes told in Soviet Estonia.
\end{abstract}

Key words: Jüri Viikberg, macaronic style, political jokes, puns, Russian loans, Soviet Estonia, Soviet jokes, Soviet leaders

\section{SOURCES OF EMPIRICAL MATERIAL}

In the USSR and the so-called Soviet bloc in general, the telling or collecting of 'anti-Soviet' political jokes was forbidden and violators were prosecuted, and it was almost impossible to research these. In spite of that, many people secretly collected such jokes. One such person was Jüri Viikberg, a well-known Estonian dialectologist from the Institute of the Estonian Language. The Folklore Department of the Kreutzwald Literary Museum (now the Estonian Literary Museum) in Tartu continually received various kinds of prohibited recordings. While the materials could not be officially archived, they were not destroyed, and were stored separately in a special archival cabinet. In 1989, Viikberg's large collection (about 4,500 joke texts), together with other similar material, was eventually made available through declassification. 

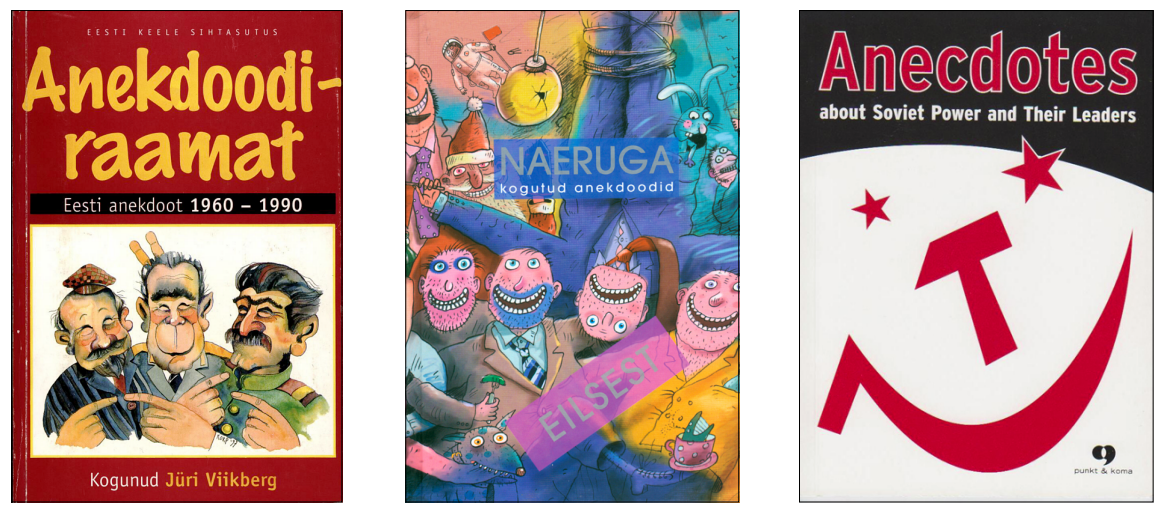

Figure 1. Joke books by Jüri Viikberg.

A selection of jokes collected by Viikberg (about 2,300 verbal joke texts plus a small number of droodles) was issued in 1997 under the title Anekdoodiraamat: Naeruga eilsest: Eesti anekdoot 1960-1990 ('A Book of Anecdotes: Laughter from Yesterday: Estonian Anecdotes from 1960-1990') and reprinted in 2004. In 2003, an even smaller selection of Viikberg's joke material entitled Anecdotes about Soviet Rule and Its Leaders: Collected from Estonia 1960-1986 was published in English.

In addition to Viikberg's book, the material collected by my wife Luule Krikmann (about 550 joke texts transcribed from 1965 to 1989, the date of 47 of these unspecified) constitutes another main source (the material is available at http://www.folklore.ee/ kriku/HUUMOR/soviet.htm).

About 800 texts of material on the political anecdotes of children recorded in more recent times by Kadi Sarv were used as supplementary material (Sarv 1996-1998; Sarv 1994 in Estonian; Sarv 1997 in English).

\section{THE MAIN PRESUMPTIONS}

The study attempts to test two strong hypotheses: First, the period of Brezhnev's rule (and particularly the last part of it) was a golden era of joke-making in the former USSR and possibly in the countries of the Eastern Bloc in general, and second, a great amount of joke material (especially political jokes) that circulated in Estonia in the Soviet period was of Russian origin.

The histogram on the next page (Fig. 2) shows the summary of the number of texts annually recorded by Jüri Viikberg and Luule Krikmann in the period 1959-1990. 


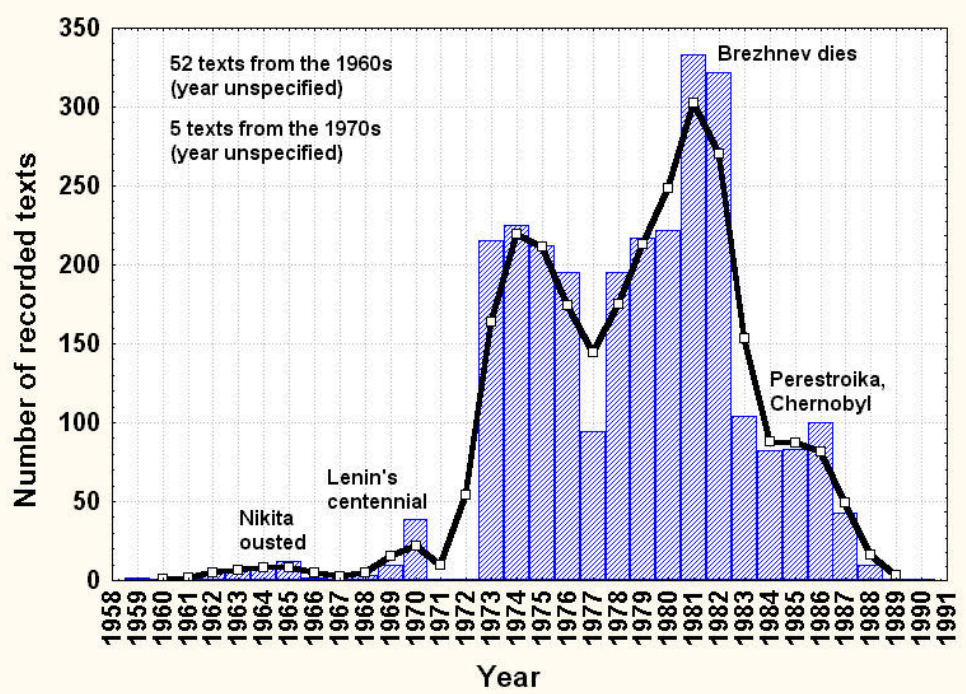

Figure 2. Summary of the number of texts annually recorded by Viikberg and Krikmann in the period 1959-1990.

Of course, the statistical resultant of such folkloric material generally reflects two overlapping attributes: the extent of the tradition (in this case, joke-telling), and the extent of collecting activity. It is possible that the level of joketelling tradition in the 1960s, as indicated in Figure 2, was incredibly low because of people's fear of and/or lack of interest in collecting such sensitive material. Viikberg only commenced active collection work in the 1970s, and practically all of his records that fall under the category '1960s' are retrospective reminiscences. Nevertheless, the annual numbers clearly indicate fluctuations at the time of Khrushchev's removal (1965) and Lenin's centennial (1970). It is clearly impossible to ascribe the explosive growth in the number of jokes in the 'Brezhnev era' (and particularly in the last two years of his life) to collecting circumstances. In the following two years, when the Kremlin gerontocrats Yuri Andropov and Konstantin Chernenko were in power, joke-telling dwindled considerably. Mikhail Gorbachev's perestroika with its temperance campaign and the Chernobyl catastrophe in 1986 brought about only a slight increase, but the following sudden upsurge of ideas about national independence very soon destroyed the appeal of Soviet jokes once and for all.

In order to test the second hypothesis about the strong Russian influence on jokes told in Soviet Estonia and the high percentage of plots and motifs borrowed from Russian, I tried to ascertain (exact or at least approximate) Russian equivalents to the Estonian plots that could be found in ideologically 
laden and/or "Russian-minded" thematic chapters of Viikberg's book. In order to accelerate this process, I left aside all printed sources and only used material yielded by the Russian search engine Rambler on the Russian Internet. The results (i.e. Estonian text examples with Russian counterparts) are available on the website http://www.folklore.ee/ kriku/TRANSPORT/SovEstRus.doc

Despite the fact that the topics have become obsolete, the late origin of the Internet texts, and the eventual inadequacies in the search, the results were quite impressive (see Table 1).

Table 1. The share of Russian loans in the thematic groups of jokes told in Soviet Estonia.

\begin{tabular}{|c|c|c|c|c|c|}
\hline \multirow{2}{*}{$\begin{array}{l}\text { Thematic } \\
\text { chapter }\end{array}$} & \multirow{2}{*}{$\begin{array}{l}\text { Number } \\
\text { of plots }\end{array}$} & \multicolumn{2}{|c|}{ Russian equivalents } & \multirow{2}{*}{$\begin{array}{l}\text { Originally } \\
\text { Estonian }\end{array}$} & \multirow{2}{*}{$\begin{array}{c}\text { Unknown } \\
\text { Origin }\end{array}$} \\
\hline & & $\begin{array}{c}\text { Absolute } \\
\text { No. }\end{array}$ & $\%$ & & \\
\hline Juku ( Rus Vovochka) & 77 & 61 & 79 & 5 & 11 \\
\hline Jew $\sim$ Rabinovich & 78 & 71 & 91 & 1 & 6 \\
\hline Chapaev, Pet'ka, Anka & 88 & 84 & 95 & 0 & 4 \\
\hline Chukchi & 82 & 71 & 87 & $2 ?$ & 9 \\
\hline Pushkin & 15 & 5 & 60 & $1 ?$ & 9 \\
\hline Lenin & 32 & 30 & 94 & 0 & 2 \\
\hline Stalin & 15 & 11 & 73 & $1 ?$ & 3 \\
\hline Khrushchev & 32 & 24 & 75 & $1 ?$ & 7 \\
\hline Brezhnev & 116 & 94 & 81 & $2 ?$ & 20 \\
\hline Andropov \& Chernenko & 19 & 17 & 89 & 0 & 2 \\
\hline Gorbachev & 39 & 23 & 33 & $2-3$ & 13 \\
\hline "Men of the Kremlin" & 27 & 14 & 52 & 1 & 12 \\
\hline Heads of state & 26 & 17 & 65 & 0 & 9 \\
\hline Different nationalities & 105 & 90 & 86 & 1 & 14 \\
\hline Sum /Average & 751 & 612 & 81 & & \\
\hline
\end{tabular}

The percentage of Russian loans was the highest for the thematic chapters 'Chapaev' (95), 'Lenin' (94), 'Jew' (91), ‘Andropov \& Chernenko' (89), and ‘Chukchi' (87). I have purposely omitted from the table chapters on sex, married couples and lovers, doctors and patients, cops, drunkards, animals, as well as instances of absurd, black and English humour (including jokes about madmen, cannibals, good and bad news, etc.), as in these instances the Western jokes may have strongly influenced the material available on Russian websites, and the latter thus serve as mediators of these jokes.

Poruchik Rzhevsky and Stirlitz, who are highly popular figures in Russian jokes, were almost non-existent in my empirical evidence of the Estonian material. In Estonia, several plots originally connected with Rzhevsky are transferred to other characters, mainly Pushkin or Chapaev. The character of Stirlitz 
is evidently too Russian-bound and untranslatable to be entrenched in Estonian jokelore.

In any case, the percentages in the table above are definitely nothing more than minimums that can only increase when the search for parallels continues.

\section{THE TEMPORAL DYNAMICS OF THE POPULARITY OF SOME CHARACTERS}

As the bulk of the joke records used were exactly or indefinitely dated, it was easy to estimate the temporal dynamics of some of the most productive joke characters (i.e. the frequencies with which their names were used) at different intervals in the period 1959-1990. In order to improve the reliability of the results, the 32-year period was divided into four sub-periods:

(i) Nikita's era (1959-1964);

(ii) early Brezhnev era (1965-1973);

(iii) late Brezhnev era (1974-1982);

(iv) the era of the "oldsters" (Andropov, Chernenko), Gorbachev (1983-1990?).

Texts with vaguely specified dates such as '1960s' and '1970s' were in the most reasonable way placed in sub-periods (i)/(ii) and (ii)/(iii), respectively.

Table 2a. Frequencies of some joke characters in the four sub-periods of the Soviet era.

\begin{tabular}{|c|c|c|c|c|c|c|c|c|c|c|}
\hline Period & Juku & Jew & Chapaev & Chukchi & Lenin & Stalin & Nikita & Brezhnev & Gorbachev & $\Sigma$ \\
\hline $\mathrm{i}$ & 2 & 1 & 0 & 0 & 1 & 9 & 21 & 0 & 0 & 34 \\
\hline ii & 18 & 13 & 12 & 0 & 52 & 10 & 7 & 14 & 0 & 126 \\
\hline iii & 57 & 108 & 84 & 48 & 63 & 25 & 21 & 316 & 0 & 722 \\
\hline iv & 10 & 15 & 2 & 73 & 7 & 11 & 7 & 27 & 47 & 199 \\
\hline$\Sigma$ & 87 & 137 & 98 & 121 & 123 & 55 & 56 & 357 & 47 & 1081 \\
\hline
\end{tabular}

Table 2b. Density of connection of different joke characters with different sub-periods of the Soviet era.

\begin{tabular}{|c|c|c|c|c|c|c|c|c|c|}
\hline Period & Juku & Jew & Chapaev & Chukchi & Lenin & Stalin & Nikita & Brezhnev & Gorbachev \\
\hline i & 0.7 & 0.2 & 0.0 & 0.0 & 0.3 & 5.2 & 11.9 & 0.0 & 0.0 \\
\hline ii & 1.8 & 0.8 & 1.1 & 0.0 & 3.6 & 1.6 & 1.1 & 0.3 & 0.0 \\
\hline iii & 1.0 & 1.2 & 1.3 & 0.6 & 0.8 & 0.7 & 0.6 & 1.3 & 0.0 \\
\hline iv & 0.6 & 0.6 & 0.1 & 3.3 & 0.3 & 1.1 & 0.7 & 0.4 & 5.4 \\
\hline
\end{tabular}

The numerical data obtained are shown in Table $2 \mathrm{a}$. Table $2 \mathrm{~b}$ estimates the correlation between particular time periods and joke characters via so-called colligation coefficients (or "bivariate percentages") that are calculated from the formula 


$$
\lambda_{A B}=\frac{A \cap B \times \sum_{t a b}}{\sum A \times \sum B}
$$

where $A \cap B$ is the number of co-occurrences (intersections) of events $A$ and $B$, $\Sigma A$ and $\Sigma B$ are the sums of frequencies of these events in the given collection and $\Sigma_{t a b}$ is the total sum of all numerical data in the table;

If $\lambda=1$, the events are regarded independent, $\lambda>1$ means positive and $\lambda<1$ negative connection.

I will also add a brief comment to each.

Juku, Chapaev, and Jew: the frequencies are relatively low; the Jew's curve probably corresponds to the waves of the emigration of Jews from the USSR; I find Chapaev's curve inexplicable.

The Chukchi character is also a relative newcomer in Russian jokelore according to Draitser (1998: 75), the Chukchi jokes first appeared in Russia in the early 1970s. Thus its zero occurrence in Estonian jokes of the sub-period (ii) may be the result of a fully predictable 'phase shift'. The absurdity of Chukchi lore, however, seems to have been particularly congenial to the surrealistic atmosphere of the collapsing Soviet Union, and the productivity of the lore thus increases exponentially in the last two sub-periods.

Soviet leaders from Lenin to Gorbachev have generally been the most popular joke material at the time a given leader was in power and/or in the nearest contiguous periods. The only exception is Lenin, due to the long and ludicrous preparations for his centennial in 1970, which became an inexhaustible source of inspiration for Soviet joke-makers. The notable superiority of the relative "popularity" of jokes about Nikita in period (i) over jokes about Brezhnev in period (iii) - 11.9 and 1.3, respectively - may partly result from the erroneous apportionment of the vaguely dated ' 1960 s' texts under periods (i) and (ii), and partly from the fact that a greater collection usually has more degrees of freedom, and thus diminishes the individual frequencies of its constituents.

\section{ESTONIAN-RUSSIAN MACARONIC TEXTS}

I think it would not be wrong to say that of all of the nationalities of the former USSR, the Estonians were the least fluent in Russian. Even so, the Estonians of my age (70) and even much younger inevitably knew Russian quite well and were also familiar with the Soviet rhetoric, which also sounded most authentic in Russian. One widespread ethnic stereotype about Russians was their huge 
store of vulgarisms and obscenities, including the notorious ' $m a t$ ', 'iks - igrek $i$ kratkoe', etc., and the skilful use of these. It is a linguistic commonplace that such vocabulary sounds much ruder in one's mother tongue than in another language. During the Soviet period, it was quite customary for Estonians to use Russian when there was a need to be particularly "expressive".

The bulk of Soviet jokes was originally created in Russian, admittedly by the Russian urban intelligentsia, and fully exploited the most elaborate phraseological, stylistic and figurative devices of the Russian language. Russian jokes in general tend to be untranslatable, or "verbal", according to Salvatore Attardo (see, e.g., 1994: 95ff), so their translations more often than not turn out to be merely pale "referential" (again, in Attardo's terms) shadows of the originals - see, for example, Raskin's (1985: 170-177) translations of chastushkas. At the same time, Russian jokes were irresistibly attractive not only because of their witty, striking, and topical content, but also because of the wild beauty of their language. I have absolutely no knowledge (and do not know whether anyone else has) of how the jokes were told in culturally and linguistically diverse parts of the USSR. In order to fill that gap, the essential body of Soviet jokes needs to be archived and numbered.

My personal experience, as well as the texts used herein, firmly attest that in Estonia, (anti-)Soviet and other jokes of Russian origin were typically told in macaronic language, maintaining the necessary untranslatable fragments of text in Russian - first of all, elements of direct speech, such as puns, punchline formulae, etc. A total of 524 (18\%) of the 2,856 texts included such fragments, sometimes in grammatically correct, but more often in broken Russian.

In presenting the examples below, the problem is not the abundance of macaronic text in Soviet Estonian jokes, but how to convey these in English in four simultaneous roles: translating the Estonian parts of the texts, conveying the two different meanings of Russian puns, and using it as a metalanguage to explain the relationships between these two planes of meaning.

Here are just a few examples:

\section{- Example 1}

Tšapai ja Petka tulevad hommikul lakast ja lähevad seina äärde kusele. Petka vaatab Tšapajevi pikka valget ööhamet ja ütleb: Знаешь, Василий Иваныч, ты прямо как Джавахарлал Неру. Т̌̆араi saab vihaseks: Совсем не важно, кого я харлал. А как уж харлал, тогда не Неру, а Нюру. Viikberg, p. 47 (recorded in 1973)

One morning Chapai and Petka come down from the barn's loft, where they had been sleeping, and take a leak against the wall of the barn. 
Petka looks at Chapaev's long white nightgown and says: "You know, Vasili Ivanych, you look exactly like Jawaharlal Nehru." Chapai thinks that "dzhavaharlal" is the past form of some (actually non-existing) foreign verb "(dzhava)harlat", meaning 'fuck', and that "neru" is the accusative form of (also non-existing) woman's name Nera, and gets angry: "It's none of your business with whom I "harled" (i.e. 'fucked'). And even if I did, it wasn't Nera but Niura [the latter is a common Russian woman's name]."

\section{- Example 2}

Tšuktš on Moskvas ja läheb restorani sööma. Naisettekandja tuleb ja tšuktš ütleb: Пожалуйста, мне список блюдей. Ettekandja ütleb: Вы имеете в виду меню? Tšиktš vaatab teda hindavalt ülalt alla ja ütleb: Потом посмотрим. Может быть и тебю.

Viikberg, p. 446 (recorded in 1986)

A Chukchi goes to have lunch at a restaurant in Moscow. The waitress approaches and the Chukchi asks her: "Please, bring me "spisok bliudei" [which is close in meaning to 'the list of foods' but sounds a lot like "bliadei", the plural genitive of "bliad" ('whore', 'hooker')]." It remains unclear which of the two meanings the Chukchi intended, probably the latter. The waitress asks: "Do you mean the menu?" The Chukchi again misunderstands - he thinks that "meniu" is the accusative of the first person pronoun "ia" (i.e., 'Do you mean me?'; the grammatically correct accusative in Russian is "menia"), transposes this broken form to the second person, hence "tebju", and answers: "We'll see, perhaps "tebiu" (i.e. 'you' in singular) as well."

Sometimes Russian is used without obvious necessity, only for the purpose of making the direct speech sound "more Russian":

\section{- Example 3}

Kaks vanatüdrukut ajavad juttu ja üks rä̈̈gib teisele: Ты смотри, как везет Нюрке. Она замужем, у нее любовник аккуратный и мало того, вчера вечером ее изнасиловали.

Viikberg, p. 473 (recorded in 1973)

Two old maids are talking and one of them says: "Look how lucky Niurka is. She is married, she has an "akkuratnyi" (or 'good') lover, and to top it all off - last night she was raped." 


\section{IS THERE SOMETHING PURELY ESTONIAN?}

Of course there is. Viikberg's book also includes a special chapter entitled 'Something Estonian'. Regrettably enough, researchers of contemporary folkloric jokes have nothing comparable to Hans-Jörg Uther's folktale register (2004), or ATU, at their disposal. Time and again I found myself unable to distinguish between jokes of purely Estonian origin and Estonian adaptations of internationally known jokes.

A joke can be regarded as genuinely Estonian if it is inspired by events that actually took place in Estonia and are unknown and/or not of interest elsewhere, or if the text includes some expressions that cannot be literally translated into another language, such as puns, idioms, rhyming parts, etc., or if it quotes, with irony, some commonplace expression in Estonian literature, or if the joke can be considered a parody of a well-known song in Estonian, etc. Different elements of 'Estonianness' may often co-occur in the same joke text.

Two events seem to dominate as sources of inspiration for Estonian jokemakers: the case of milkmaid Leida Peips and the 1980 Olympic regatta in Tallinn.

A common honorary title in the USSR was the Hero of Socialist Labour, awarded to distinguished working people. These people were extensively discussed in newspapers, they were elected to various councils and committees and were thus presented as symbols and icons of the might of the Soviet Union and the Soviet people's enthusiasm for work. The earliest heroes of Socialist labour were coal miner Aleksei Stakhanov and Pasha Angelina, the first female tractor-driver, in the 1930s. In the mid-1970s, the humble Estonian milkmaid Leida Peips, who was unfortunate enough to attract such unwanted attention, was extensively written about in newspapers, elected to the Supreme Soviet, personally introduced to Leonid Brezhnev - and pitilessly mocked in Estonian jokes.

I can once again offer only a few examples of purely Estonian jokes, but I again have difficulty in explaining their funniness to the non-Estonian public.

\section{Examples of the 'Leida Peips cycle'}

In order to be able to understand the jokes, some preliminary tips are provided below.

1) In Estonian, as in any other language, jokes are often made through the use of comical, parodizing acronyms.

2) In Finnish and Estonian, alliteration reminiscent of old runo songs is one of the main structural features, and there is a strong tendency to- 
wards alliteration in Estonian folklore in general, including the alliterative formulae of Estonian "homemade" jokes.

3) 'Peipsi' is the name of the big lake in the eastern part of Estonia, half of which lies on the territory of Estonia, the other half reaches into Russia. In the 1970 s, skimmed milk was called Peipsi vesi 'Peipsi water'.

\section{- Example 4}

Tip for understanding: In Estonian the quasi-word pronounced ['El] is a euphemism for lits ('whore', 'hooker').

3 suurt L-i: Leida, Lehm, Ljonja .

Krikmann, no. 525 (date unspecified)

Literally: Three big 'L-s': Leida, cow, Lionia (= Brezhnev).

\section{- Example 5}

Leidale tuleb külla Ljonja. Uksel on silt LOLL (= Ljonja, olen laudas. Leida). Nuhk hakkab uurima, kes kirjutas. Leida ise kirjutas!

Sama akronü̈̈mi teine mõtestus: "Lehm on lüpstud. Leida."

Krikmann, no. 533 (date unspecified)

Lionia comes to visit Leida and finds on Leida's door a sign that says LOLL, literally, 'fool', actually intended as the acronym for: "Lionia, I'm in the cowshed. Leida". A spy begins to investigate who wrote it. [It turns out that] Leida herself wrote it!

An alternative interpretation of the same acronym: "The cow has been milked. Leida."

\section{- Example 6}

Tip for understanding: In Estonian there are no voiced plosives. Thus the pronunciation of the word püsti may stand for either the genitive and partitive case of büst ('bust') or 'standing', 'standup', 'upright'.

Leida juurde tuleb kunstnik ja ütleb: “Teeme büsti.” Leida: “Ei ole aega.”

- “Teeme büsti ruttu ära, see ei võta palju aega.” - "Eluaeg ei ole püsti teinud, teeme ikka pikali.”

Krikmann, no. 537 (date unspecified)

A sculptor comes to Leida and says: "Let's make a bust (of you) [understood as 'do it (i.e. have sex) standing up (püsti)]." Leida: "I haven't got time for that." - "We'll do the bust [do it standing up] quickly, it won't 
take long." - "I have never done it standing up, let's do it lying down instead."

\section{- Example 7}

Leida Peips kirjutab Brežnevile: Kas te mäletate veel, kuidas me koos magasime? Vastus tuleb kiiresti: Kust te selle võtate? Midagi sellist pole ju olnud! - Kuidas pole olnud? Me magasime koos Kongresside Palees, teie presiidiumis, mina saalis.

Viikberg, p. 491 (1975)

Leida Peips writes to Brezhnev: "Do you still remember how we slept together?" Brezhnev rapidly replies: "What are you talking about? Nothing like that ever happened!" - "What do you mean never happened? We slept together in the Palace of Congress - you were at the presidium table, I was in the hall."

Some Leida Peips jokes are obviously mere adaptations of more widely known jokes.

\section{- Example 8}

Esimees ütleb Leidale, et homme tuleb reporter sinult intervjuud võtma. "Mis tuu om?" küsib Leida. Esimees: "Ma ka ei tea, aga igaks juhuks pane puhas kombinee selga."

Krikmann, no. 528 (date unspecified)

The kolkhoz chairman informs Leida that a reporter will come to interview her the day after. "What about?" Leida asks. "I don't know either, but put on a clean slip, just in case!"

The same motif is extensively represented on the Russian Internet.

\section{- Example 9}

Leonid Brežnev hakkab sõitma Eestisse Leida Peipsile külla. Päris täpselt ei tea, kuhu sõita, aga õnneks oli tee ääres teeviit - Peipsi 25 km. Autojuht keerab viidatud teele, kupatavad edasi. Talvine aeg, ümberringi vaadata vähe. Korraga hakkab auto läbi jää vajuma. Lähedal on sikuskimehi, Brežnev hüüab appi ja lubab täita igaühe soovid. Üks soovib maja, teine autot, kolmas mõtleb, mõtleb ja soovib endale lõpuks tinakirstu. No nii, mees päästetakse ära, sai kuivad riided selga ja kuuma ahju juurde. Siis meenutab Brežnev meeste soove ja vangutab pead: Autost ja majast saan 
ma aru, aga miks sina tinakirstu soovisid? - No kui külarahvas teada saab, kelle ma ära päästsin, läheb mul kirstu kohe varsti vaja.

Viikberg, p. 489 (1975)

In wintertime Brezhnev comes to visit Leida Peips in Estonia. He does not know exactly where she lives, but then he sees the signpost '[Lake] Peipsi $25 \mathrm{~km}$ ', and his chauffeur turns toward the lake. They are driving, and suddenly the car begins to sink through the ice. Fortunately there are some winter fishermen nearby and they save Brezhnev's life. The thankful Brezhnev promises to do for them whatever they want. One wants a house, the second a car, but the third man wants a tin coffin. The puzzled Brezhnev asks why he would need a coffin. - "Well, when the village people find out who I saved, I will soon need a coffin."

Cf. the German text under no. 39 in Krikmann 2004:

Stalin, der nicht schwimmen konnte, badet im Schwarzen Meer und ist dabei, zu ertrinken. Ein Landsmann rettet ihn. "Welchen Lohn möchtest du," fragt Stalin. "Sagen Sie niemandem, dass ich Sie gerettet habe. Das soll mein Lohn sein." (http://www.matrjoschka-online.de/archiv/ marginalien.htm)

\section{Name pun jokes: Karl Vaino and Vaino Väljas}

Tips for understanding the jokes below:

1) the surname of the first man and the forename of the second man coincide;

2) The Estonian word väljas also means 'out', 'outside', and 'outdoors'.

\section{- Example 10}

At the end of the 1980s, when the Singing Revolution began in Estonia, the detested Karl Vaino, half-Estonian General Secretary of the Estonian Communist Party, was replaced with the more democratically-minded man, Vaino Väljas. I saw students at one demonstration carrying the slogan with a pun: HURRAA, VAINO VÄLJAS! the first possible interpretation of which is: 'Hurrah, Vaino Väljas!', and the other: 'Hurrah, Vaino is out!'

\section{- Example 11}

Another modification of puns with the above names: 
Ei tea, kus Karl Vaino nü̈̈d ka töötab? - Ilmajaamas. - Mis ta seal teeb? - Vaatab aknast välja, et kas väljas on juba külm.

Viikberg, p. 513 (1988)

"I wonder where Karl Vaino is currently working." - "At the weather station." - "What is he doing there?" - "He's looking out the window to see... [The punchline ending has two interpretations: 1) ...whether it is already cold outdoors?", and 2) ...whether Väljas is already cold (i.e. 'dead')?”]

\section{Other pun jokes}

\section{- Example 12}

Tip for understanding: the Estonian word võitu has two homonymous meanings:

1) the partitive case of the substantive võit ('victory');

2) the headword of Estonian compound adjectives and adverbs it means 'a bit (too) ...', 'somewhat...', 'rather', '-ish' (cf. Russian -вато).

Sotsialismi 3 võitu: vähevõitu, sitavõitu, kallivõitu.

Krikmann, no. 501 (1987)

Its purely referential English approximation would be: "What are the three great triumphs of socialism?" - "Rather too few [goods], rather too shitty, rather too expensive."

\section{- Example 13}

Mees läheb õhtul valveapteegi juurde ja annab kella. Keegi pistab ukse vahelt nina välja ja küsib: Mis vaja? - Kas teil preservatiive on? küsib mees. - Ei. Otsas juba. - No andke siis otsast.

Viikberg, p. 489 (1975)

The referential translation: In the evening a man goes to the all-night chemist's and asks: "Have you got condoms?" - "No, [the following "Otsas juba" has two different meanings: 1) '...we have already sold out' and 2) '...they are already on the tip']". - "Well, then give me one from the tip!"

\section{- Example 14}

Tip for understanding: The Estonian phrasal verb läbi tõmbama has two different meanings: 1) 'cross something off/out', 'strike something out'. 'delete'; 2) as an idiomatic expression, 'fuck', 'shag'. 
Neiu saab 16-aastaseks ja läheb passilauda passi saama. Saab passi kätte, aga perekonnaseisu lahtrisse on kirjutatud “lesk”. Läheb miilitsaülema juurde protestima ja see tõmbab "lesele” kriipsu peale. Passiülem kirjutab oiendi: Miilitsaülema poolt läbitõmmatud “lesk” lugeda "neiuks”.

Viikberg, p. 494 (1977)

A 16-year-old girl goes to the passport office to receive her first passport. She finds that her marital status is marked 'widow' and goes to the head of police to protest. The head of police crosses out the word 'widow' and the head of the passport office replaces it with the note:... [The note has two meanings: 1) "(the word) 'widow' crossed out by the head of police is to be considered a maiden"; 2) (punctuation disregarded) "the widow shagged by the head of police is to be considered a maiden".]

\section{Examples of 'grammatical jokes'}

\section{- Example 15}

Kas tead, et eesti keeles käänatakse asesõnu nü̈̈d uut moodi: minantropov, sinantropov, temantropov...?

Viikberg, p. 505 (1982)

Do you know that Estonian pronouns are now declined in a new way: 'I-antropov', 'you-antropov', 'he-antropov'...?

Estonian singular personal pronouns are: mina, sina, tema.

"Sinantropov" is a clear allusion to Sinanthropus.

\section{- Example 16}

There is a joke cycle about Soviet "newspeak" names for Estonian cases and the mood of Estonian verbs that needs more detailed explanation.

Tip for understanding: In Estonian, nouns are inflected according to 14 cases, which have names derived from Latin and (now rather archaic) parallel names derived from Estonian roots. These puristic terms are in principle participial adjective forms of certain Estonian verbs, ending in -tav, and in some cases, -ütlev (i.e. something like -ing and -saying in English). For example, nominative is nimetav (i.e. 'naming'), genitive is omastav (literally, 'possessing' or 'assuming'), illative is sisseütlev (interior locative, roughly corresponds to preposition 'into'; literally, 'saying to inside'), elative is seestütlev (interior locative, corresponds to preposition 'from'; literally, 'saying from inside'), comitative is kaasaütlev (associative; literally, 'saying along'), abessive is ilma- 
ütlev (privative; literally, 'saying without'), and so on. Most Estonian names for mood categories are analogously derived: imperative is käskiv kõneviis (literally, 'commanding' or 'ordering' mood), conditional is tingiv kõneviis (literally, 'conditioning' mood), etc.

Elza Grechkina, a former disliked Minister of Education of the Estonian SSR, was said to have proposed a reform of Estonian grammar, removing some allegedly archaic cases and adding new ones, such as mittemidagiütlev (literally, 'saying nothing', which stands for 'meaningless', 'senseless'), väheütlev (literally, 'saying little', or 'uninformative'), äraütlev (literally, 'saying away', i.e. 'refusing'), ilmaolev (literally, 'being without', i.e. 'doing without' or 'being deprived of'), äravõetav (literally, 'that which can be taken away'), imestav ('wondering' or 'being surprised'), ihaldav ('desiring'), mõnitav ('scoffing', 'derisive'), and new moods for verbs like umbusaldav ('distrusting') and kõhklev ('hesitating').

Cf. Viikberg, pp. 504-505; Krikmann, no. 352 (all records from 1982)

\section{- Example 17}

Kuidas pöörab Juku sõna "ehitama"? Koolis eesti keele tund ja õpetaja laseb Jukul pöörata sõna "ehitama”. Juku hakkab pihta: Mina ehitan, sina ehitad, tema ehitab, meie ehitame, teie ehitate, nemad kolivad sisse. Viikberg, p. 18 (1975)

How does Juku conjugate the Estonian verb 'build' in Estonian? - "I build, you build, he/she builds, we build ... they move in."

This joke based on grammar, though not necessarily Estonian per se, is nevertheless very Estonian in spirit. In the Soviet period, whole new residential districts were established, especially in Tallinn, but the newly constructed buildings were mostly occupied by Russian migrant workers.

\section{Jokes based on toponyms and anthroponyms}

\section{- Example 18}

Here is yet another joke about the new districts. In Tallinn their names typically ended in -mäe (genitive of mägi, i.e. 'hill'), such as Mustamäe (literally 'Black Hill'), Lasnamäe (literally perhaps 'Shovel Hill') and Õismäe (literally 'Blossom Hill'). Also, there are several cemeteries in Tallinn that have names with the same ending, such as Rahumäe (literally 'Peace Hill') and Pärnamäe (literally 'Linden Hill'). 
Iivan Käbin on Moskvas ja peab seal aru andma, kuidas edeneb Tallinna elanike paigutamine. Üldjoontes on asi lahendatud, seletab Käbin. Venelased lähevad Mustamäele, Oismäele ja Lasnamäele, eestlased Rahumäele ja Pärnamäele.

Viikberg, p. 491 (1975)

Ivan Käbin (the one-time leader of the Estonian Communist Party) is visiting Moscow and is reporting on the settlement of residents of Tallinn in new districts. "In general, the problem is solved," he reports, "the Russians will go to Mustamäe, Õismäe and Lasnamäe, and the Estonians to Rahumäe and Pärnamäe.”

\section{- Example 19}

Perhaps the greatest of the Soviet Estonian puns that I know is the one about Gustav Naan, an Estonian Marxist philosopher and alleged encyclopaedist, one of the rewriters of Estonian history in the Marxist spirit and later cosmologist and charismatic freethinker to some people, a despised careerist and schemer to others.

The pun was very topical in the 1980 s, but is represented in my material by a single record:

Mis on erinevat Soomes ja Eestis? - Noh? - Soomes on pestav tapeet ja Eestis on Gustav Naan.

Viikberg, p. 504 (1982)

What's the difference between Finland and Estonia? - What? - In Finland they have washable wallpaper, in Estonia we have Gustav Naan.

Tips for understanding:

1) Estonian deverbal adjectives ending with -tav are partly equivalent to these ending with -able in English;

2) with no voiced plosives in Estonian, the pronunciations of the name Gustav and the word kustav are equal;

3) kustav means 'pissable', which is quite nonsensical in both English and Estonian.

\section{Jokes based in various ways on popular songs}

\section{- Example 20}

Isaak Dunaevski wrote music for many Soviet films in the 1930s. One of his hit songs is the brave and optimistic 'Марш веселых ребят' ('The March of Jolly Fellows') from the movie Веселые ребята ('Jolly Fellows', 1934). The opening 
line of its second stanza is "Нам песня строить и жить помогает...", which was translated into Estonian as "Meil laulud aitavad elada, võita" ('Songs help us to live and win'). It was enough to remove the comma from the clause to get a terrific pun 'Songs help us to live without butter'.

Tip for understanding: the homonymous võita is 1) the $d a$-infinitive from the verb võitma ('to win') and 2) the abessive case of the substantive $v \tilde{i} i$ ('butter'; hence, 'without butter').

Cf. also Krikmann, no. 238, 297 (1981/2)

\section{- Example 21}

Another popular song in 1960s' Estonia was entitled 'On kallis mulle kodupaik' ('My home is dear to me') by Estonian composer Gennady Podelski. It has a nice melody and its content (as is generally the case with popular songs) is absolutely trivial, especially in literal translation without any support from melody, rhyme, and rhythm: 'My home is dear to me, / It's so good to be here, / It's so good to be here, / So many good impressions / You always take along from here', and so on in the same spirit.

Evidently, it was possible to make something out of this insipid apolitical banality:

Kuidas ja mida laulavad üldlaulupeol ühendkoorid? Eestlased laulavad: "On kallis mulle kodupaik ...” Ja venelased: “... nii hea on olla siin, nii hea on olla siin ...”

Viikberg, p. 502 (1981)

How do the mass choirs sing this song at the song festival? Estonians sing: "My home is dear to me...", and the Russians: “...it's so good to be here, it's so good to be here..."

The last line was usually delivered in a thick Russian accent.

\section{- Example 22}

An conventional Estonian translation of the well-known rhyme 'What Are Little Boys Made Of? [...] What Are Little Girls Made Of?' is quite close to its original:

Boys are made of "hiirest ja konnast ja kutsika hännast” (i.e., 'a mouse and a frog and a puppy's tail'), and girls, mutatis mutandis for "suhkrust ja jahust ja maasikavahust" (i.e., 'sugar and flour and strawberry cream'). This inspired the following ethnopolitical joke: Millest on tehtud väikesed venelased? - Tatist ja vatist ja joptvojumatist.

Krikmann, no. 120 (1978) 
Literally: What are little Russians made of? - Snot and cotton and "motherfucking".

\section{- Example 23}

Tips for understanding:

1) there is a semi-folkloric belief that stutterers do not stutter when singing;

2) there is a popular nonsensical children's song in Estonia "Hiir hüppas, kass kargas, / vana karu lõi trummi, / kirp aknast välja, / nahkpüksid jalga" (The mouse jumped and the cat sprang / And the old bear beat the drum, / Throw the flea out the window, / Put on lederhosen');

3) one of Tartu's run-down districts is called Supilinn ('Souptown'), in which there are street names Pea Street, Bean Street, Pod Street, Potato Street, Melon Street, Berry Street and others.

Maja läks põlema ja kokutaja pidi teatama tuletõrjesse. Veider nähtus küll, aga lauldes kokutajad ei kokuta ja nii laulis see ("Hiir hüppas, kass kargas" viisil) telefonitorusse: Meil Herne tänavas põleb üks maja! Torust vastati:Trillallaa-trallallaa, pane toru ära!

Viikberg, p. 490 (1975)

A house caught fire and a stutterer had to call the fire department. It's an interesting phenomenon that when people sing they don't stutter, and thus the stutterer called the fire department and sang (to the tune of the children's song): "In our Pea Street / There's a house on fire..." The fire department dispatcher sang in response: "Hey-ho-hey-ho, / Hang up the phone!"

I am not certain whether this joke was born in Tartu, but non-Estonian equivalents are hard to come by for the reason that there is no international joke index.

Both the relative frequencies of macaronic Estonian-Russian texts and texts of Estonian origin, including adaptations of jokes throughout the four sub-periods seem to be on the rise. The tendencies are not incompatible or contradictive, but rather indicate, on the one hand, growth in the general linguistic diversity in Estonian joke texts (as the percentage of text fragments in English, German, Latin etc. also increases), and, on the other, boost in national self-confidence. 


\section{THE INTERNAL TYPOLOGICAL STRUCTURE OF THE REPERTOIRE OF CANNED JOKES}

Perhaps it is regrettably non-postmodernist, too "folkloristic" and "archivistic" to speak of the typological structure of the international store of canned jokes. Nevertheless, my previous experience in studying different folkloric genres of several nations encourages me to argue that such a structure really does exist and, moreover, it is important to know about it.

No joke, as an individual text (conveyed orally or presented on paper or on the Internet), exists in a vacuum, but is in various ways - associatively, genetically, or otherwise - connected with other texts preserved in the collective memory and shared among the members of joke-making communities. They also interact with events and situations in the outside world, retrieving jokes from this collective memory and restoring them in other memories when they are told. Nor is the sum total of hitherto told and/or stored jokes a chaotic mess, but a multidimensional set of natural classes consisting of natural typological units (joke 'items', or plots), whose borders are in some cases clear-cut and in some cases hopelessly fuzzy.

There are powerful joke items that are capable of "wandering" from country to country and from language to language. That is, for example, the case with the majority of East European political jokes published by Banc \& Dundes (1990), which are known in many countries of the Eastern Bloc and display considerable variation, or the most widely spread examples from my Stalin book (Krikmann 2004), such as the "Who sneezed?" joke (No. 1), the joke about the stopped train of Socialism (No. 2), about camp loads of collected jokes (No. 3 ), and many others. There are other joke items that have little or no chance of reaching beyond the borders of a particular language, simply because they are untranslatable, as can be seen in the above-mentioned examples of Estonian political puns.

My experience in working with the extensive archival material on some genres of Estonian and Finnic folklore also suggests that the typological items (or, in terms of jokes, different plots) usually tend to follow a Zipfian type of frequency distribution: There is a great number of infrequent ("feeble", local) plots, a mean number of plots of "medium frequency" and a small number of very frequent (effective, global) plots. 


\section{IN LIEU OF A CONCLUSION: SOME GENERAL ISSUES OF SOVIET AND SOCIALIST JOKES}

My paper purposely avoids touching upon the general issues connected with Soviet and Socialist jokes, their fundamental nature and characteristic features, the problem of their functions, etc. The available literature on these topics is too immense to be embraced within the limits of a single article, and the results that have been obtained so far are still too preliminary and contradictory, and the empirical base of research is too scanty and fragmentary. Due to the limitations of my topics and space, I must tacitly bypass all but the monographs by Emil Draitser (1998) and Seth Graham (2003), the extensive overview of Russian Soviet-era jokes by Bruce Adams (2005), as well as rich Russian sources, including the early books by Yuri Borev (1990; 1992; 1995), the monograph on Russian jokes about Stalin by Alexandra Arkhipova and Mikhail Mel'nichenko (2008) and many, many others.

Perhaps the most reliable insights into the topic are those provided by Christie Davies (2007; 2009) and Liisi Laineste (2005; 2008; 2009). Thanks to these studies we now have some promising preliminary statements and hypotheses about Soviet and Socialist jokes to work with:

1) Soviet and Socialist jokes did not function mainly as tools of protest and resistance, or as signs of cynical resignation, surrender, alienation and pessimism (as Yurchak 1997 and Graham 2003 have claimed), or as psychological opiates or 'safety valves' (as Rose 2001/2002 and others have claimed). They are rather "a thermometer not a thermostat; they can be used as an indication of what is happening in a society but they do not feed back into the social processes that generated them to any significant extent" (Davies 2007: 300).

2) Under the Soviet and other Socialist regimes, practically all kinds of jokes are prone to becoming political and economic jokes; political and ethnic jokes were not in different categories as they are in democratic countries, but were largely interwoven and connected.

3) Ordinary treatments of ethnicity in Soviet jokes by Draitser (1998), Shmeleva \& Shmelev (2002) and others usually share the Russo- and/or Judeo-centric point of reference, and thus also share Christie Davies' view of the one-sided, 'from centre to periphery', 'from dominant to dominated', 'from modern to obsolete', 'from higher to lower', etc. direction of ethnic mockery. However, as Liisi Laineste (2005 and later) has shown, the ethnic jokes of Soviet Estonia do not precisely follow Davies' postulates: "On the contrary, as a rule, jokes are made on ethnic groups higher up the social scale (e.g., Estonians about the 
Russians)" (Laineste 2005: 21). This may very likely hold true for jokes of the non-Russian part of the former Eastern Bloc in general. These nationalities hold the stereotype of Big Brother. Big Brother spoke in Russian and the stereotype embodied a threat to the suppressed nationalities, not only because of Russia's displays of military power and the economic plight but also because it aimed to wipe out non-Russian languages and assimilate these into Russian, at least within the borders of the USSR. Therefore it is reasonable to presume that political and ethnic aspects were largely interwoven and blended in the jokes of the suppressed peoples of the Eastern Bloc in general.

The joke material in Jüri Viikberg's book is organised according to a specific two-tiered system of categories, partly based on the content, and partly on the form of the jokes. Viikberg has included a number of droodles and practical jokes in conundrum form. The categories of lower level are most frequently connected with certain politically, ethnically, sexually or otherwise specified key personae, such as leaders of the Soviet Union and other countries, Chapaev, Chukchi, Jew, Russian, Estonian, Juku, married couples, cops, doctors, madmen, cannibals, various animal characters, etc. Thus Viikberg's system largely involves levels (2), (3) and (4) of the General Theory of Verbal Humour (GTVH) model of jokes proposed by Attardo and Raskin (1991), that is, narrative strategies ('genre forms'), targets (butts, personalised objects), and situations.

Political aspect, ethnicity and sexuality - the principal moving powers of jokes largely investigated by Raskin (1985 and later), Davies (1990 and later), and many others - do not provide the means for splitting the general joke store into three mutually exclusive parts. Instead, these are aspects that often appear in twos and threes in the same joke. Furthermore, they do not exhaust the entire set of the criteria for funniness.

Below I will attempt to briefly delineate my own somewhat fuzzy and incomplete vision of the categorisation of Soviet Estonian jokes (and perhaps jokes of many other peoples of the former Eastern Bloc) at a more generic level.

As stated above, it is the mainstream tendency in Soviet and Socialist jokes to politicise all kinds of jokes and to intertwine and mix ethnic jokes with political ones. At the same time, Soviet-era Estonian material provided by Viikberg and Krikmann, as well as the entire Russian material, clearly shows an opposite tendency - the disappearance of former political and/or ethnic markers of some joke characters, such as Chapaev, Chukchi, Lenin, or Stalin.

Furthermore, various scenarios of development are possible. If the cluster of joke plots labelled with a certain character's name is large enough and thus has a necessary amount of inertia, the name label can survive, despite its being deprived of former political and/or ethnic markers, referring henceforth 
to some mythologised or trickster-like character. If an individual plot in which they occur happens to possess other values beside political and ethnic ones, it can continue its existence, perhaps in a modified form and with shifted emphases.

What are these "other values"? First of all, the sexual factor that has been salient in jokes of all eras and is now all the more supported by the tendencies of the cult of sex and the rampant sexual freedom in contemporary society.

The last, peripheral part of Viikberg's book displays the supposedly strengthening third factor. In contemporary jokelore there are already large and probably expanding areas of absurd and black humour, such as the 'dystrophic cycle' in Russia or the 'Orbit cycle' in Estonia and elsewhere, as well as cannibal jokes, good and bad news jokes, etc., where Bergson's "anaesthesia of the heart" seems to be more than total, the fundamental laws of nature and logic do not seem to apply, the whole view of the world obtains a surrealistic character, allegories obtain a new, hitherto unexplained quality, etc.

Thus at the highest generic level, the store of Soviet Estonian jokes can tentatively be divided into three large and fuzzy groups:

1) the cluster of ethno-political jokes of mainly Russian origin and with a decreasing trend of future development;

2) the cluster of sexual jokes of a universal nature and with a continuing or increasing trend of development:

3) the cluster of abstract and/or absurd and/or reality-distorting jokes of mainly Western origin and with a strongly increasing trend of development.

Of course, the above postulates should not be taken too seriously. And once again, in order to specify, corroborate or refute these (or any of the various hypotheses), we need an "ATU of contemporary jokes".

\section{ACKNOWLEDGEMENT}

This study was supported by Estonian Science Foundation Grant No. 6759.

\section{NOTES}

${ }^{1}$ An earlier version of paper was presented at the 18th ISHS Conference at the Danish University of Education, Copenhagen, Denmark, July 2006. 


\section{REFERENCES}

Adams, Bruce 2005. Tiny Revolutions in Russia: Twentieth-century Soviet and Russian History in Anecdotes. New York \& London: RoutledgeCurzon.

Arkhipova, Alexandra \& Mel'nichenko, Mikhail 2008. Anekdoty o Staline: teksty, kommentarii, issledovaniia.Moskva: O.G.I.

Attardo, Salvatore 1994. Linguistic Theories of Humor. Berlin \& New York: Mouton de Gruyter.

Attardo, Salvatore \& Raskin, Victor 1991. Script Theory Revis(it)ed: Joke Similarity and Joke Representation Model. Humor: International Journal of Humor Research, Vol. 4, No. 3/4, pp. 293-347.

Banc, C. \& Dundes, Alan 1990. You Call This Living? A Collection of East European Political Jokes. Athens \& London: The University of Georgia Press.

Borev, Yuri 1990. Staliniada. Moskva: Sovetskii Pisatel'.

Borev, Yuri 1992. Fariseia: Poslestalinskaia epokha v predaniiakh i anekdotakh. [Pharisea: The Post-Stalin Era in Legends and Anecdotes.] Moskva: Konets veka.

Borev, Yuri 1995. Istoriia gosudarstva sovetskogo v predaniiakh $i$ anekdotakh. [The History of Soviet Empire in Legends and Anecdotes.] Moskva: RIPOL.

Davies, Christie 1990. Ethnic Humor Around the World: A Comparative Analysis. Bloomington \& Indianapolis: Indiana University Press.

Davies, Christie 2007. Humour and Protest: Jokes under Communism. International Review of Social History, Vol. 52, Supplement 15, pp. 291-305.

Davies, Christie 2009. Post-Socialist, Socialist and Never-Socialist Jokes and Humour: Continuities and Contrasts. In: A. Krikmann \& L. Laineste (eds.) Permitted Laughter: Socialist, Post-Socialist and Never-Socialist Humour. Tartu: EKM Teaduskirjastus.

Draitser, Emil A. 1998. Taking Penguins to the Movies: Ethnic Humor in Russia. Detroit: Wayne State University Press.

Graham, Seth Benedict 2003. A Cultural Analysis of the Russo-Soviet Anekdot. PHD dissertation. University of Pittsburgh. Available at http://etd.library.pitt.edu/ ETD/available/etd-11032003-192424/unrestricted/grahamsethb_etd2003.pdf, accessed in Nov 2009.

Krikmann, Arvo (ed.) 2004. Netinalju Stalinist-Internet-anekdoty o Staline - Internet Humour About Stalin. Tartu: EKM \& EKFK.

Laineste, Liisi 2005. Targets of Estonian Ethnic Jokes within the Theory of Ethnic Humour (Ch. Davies). Folklore: Electronic Journal of Folklore, Vol. 29, pp. 7-24.

Laineste, Liisi 2008. Post-Socialist Jokes in Estonia: Continuity and Change. Dissertationes Folkloristicae Universitatis Tartuensis, 12. Tartu: Tartu University Press.

Laineste, Liisi 2009. Political Jokes in Post-Socialist Estonia (2000-2007). In: A. Krikmann \& L. Laineste (eds.) Permitted Laughter: Socialist, Post-Socialist and NeverSocialist Humour. Tartu: EKM Teaduskirjastus, pp. 41-72.

Raskin, Victor 1985. Semantic Mechanisms of Humor. Dordrecht \& Boston \& Lancaster: D. Reidel Publishing Company. 
Rose, Alexander 2001/2002. When Politics is a Laughing Matter: Jokes and Tyrants and Democrats around the World. Policy Review, No. 110, pp. 59-71.

Sarv, Kadi 1994. "Mina tahan ka Nõukogude Liidus elada!": Poliitiline anekdoot koolipärimuses. ['I Want to Live in the Soviet Union Too!' Children's Political Anecdotes in School Lore.] Lipitud-lapitud: Tänapäeva folkloorist. [The ScratchyPatchy 'Kommunaar' Shoe.] Tartu: EKI \& EKM.

Sarv, Kadi 1996-1998. Poliitiline anekdoot I-V. ['Political Jokes', Parts 1-5] Mäetagused, Vols. 1/2-6. Available online at http://www.folklore.ee/tagused/nr1/nalinet.htm (Part 1), http://www.folklore.ee/tagused/nr2/nali2.htm (Part 2), http://www.folklore.ee/ tagused/nr4/nali3.htm (Part 3), http://www.folklore.ee/tagused/nr5/nalinet4.htm (Part 4), http://www.folklore.ee/tagused/nr6/nalinet5.htm (Part 5), accessed in Nov 2009.

Sarv, Kadi 1997. Children's Political Anecdotes: Register. Folklore: Electronic Journal of Folklore, Vol. 5, pp. 97-171.

Shmeleva, Elena \& Shmelev, Aleksei 2002. Russkii anekdot: Tekst i rechevoi zhanr. [Russian Joke: Text and Speech Genre.] Moskva: Iazyki slavianskoi kul'tury.

Uther, Hans-Jörg 2004. The Types of International Folktales: A Classification and Bibliography. Based on the System of Antti Aarne and Stith Thompson. Parts I-III. FF Communications 284-286. Helsinki: Suomalainen Tiedeakatemia.

Viikberg, Jüri 1997. Anekdoodiraamat: Naeruga eilsest: Eesti anekdoot 1960-1990. Tallinn: Eesti Keele Instituut.

Yurchak, Alexei 1997. The Cynical Reason of Late Socialism: Power, Pretense, and the Anekdot. Public Culture, Vol. 9, No. 2, pp. 161-188. 